\title{
Othappu in Two Tongues
}

\begin{abstract}
$\underline{\text { Abstract }}$
According to Venuti, symptomatic reading is a strategy in Translation Studies to understand how a translation consciously or unconsciously suppresses the ideological concerns in the source text. This method emerged as a reaction against the humanistic analysis of translation that dealt only with the semantic unity at the heart of the text to the point of exclusion of the ideological positions in the source text. Employing Venuti's concept of symptomatic reading, this paper examines how Valson Thampu's translation of Sarah Joseph's Othappu turns out to be a violent rewriting of the source text.
\end{abstract}

In 2008, Oxford University Press brought out the English translation of Sara Joseph's Malayalam novel Othappu by Valson Thampu under the title The Scent of the Other Side. The translation won the Crossword Translation Award for the year 2009, and was highly praised for being faithful to the rhetoric of the source language Malayalam and to the cultural milieu of its setting, the catholic community of Trichur. The review which came out in the Indian Literature (Sahitya Akademi journal) admired the translator for emerging "victorious in delicately guarding against the trespasses of language or nuance" (Antony: 251). D Babu Paul, in a review that he wrote in The Indian Express, appreciated that "Valson Thampu has succeeded in... ensuring that the beauty of Malayalam used by one of its best story tellers... is not lost in translation" (Paul, 2009). Yet it is surprising how the translation has escaped the charges of being inattentive to the ideological concerns of the source text. This 
paper is a symptomatic reading of Thampu's translation of Sarah Joseph's Othappu to study how the discontinuities in the translation hijack the politics of the source text.

Proposed by the French Marxist Louis Althusser in his Reading Capital, symptomatic reading is originally a mode of reading literary and historical works to "determine what the work is unable to say, or what it represses because of its ideological conventions" (Buchanan:462). Lawrence Venuti borrowed this concept to translation studies to examine the ideological implications brought about by the translator's infidelity to the source text at the level of diction, syntax or discourse. The symptomatic analysis was fundamentally a resistance to the humanistic analysis of translation that located only "a semantic unity adequate to the foreign text, stressing intelligibility, transparent communication, the use value of the translation in the receiving culture" (Venuti: 24). In the Translator's Invisibility, Venuti gives an example of symptomatic analysis by looking at the translations of Sigmund Freud's text for the standard edition. Venuti notes that while Freud's texts were often simple and colloquial, their translation was highly jargonized. When Freud had used the simple German word Fehlleistung meaning something like "faulty function", the translator employed the term "parapraxis" to mean the same idea. According to Venuti, the translation of Freud into a scientific discourse from a colloquial language is symptomatic of the cultural forces of the translator's time which wanted to get Freud accepted within the standard medical discourse. By reading such stylistic inconsistencies symptomatically, Venuti demystified the notion of transparency concerning translation. Through the theoretical framework of symptomatic reading, this paper studies how Valson Thampu's translation of Sarah Joseph's Othappu hijacks the source text. 
The first discontinuity that I would like to point out is the translation of the title Othappu into The Scent of the Other Side. 'Othappu' is the colloquial variation of the Malayalam word 'uthappu' meaning 'falter' or 'stumble'. The term 'othappu' is used in the Malayalam Catholic Bible to mean the act of instigating a believer to lose his/her faith in or go against the teachings of the church. This process of encouraging somebody to deviate from the path of the church need not be in the form of a direct exhortation to do so. It can also be in the form of publicly committing an act that the church despises thereby setting a model for others to do the same thing. So, before doing any action a believer is supposed to think whether this will cause 'othappu' to others. As far as the church is concerned, 'othappu' is a mechanism of control. By invoking the idea that committing 'othappu' involves moral degradation and incurs God's wrath, the church effectively prevents its members from going against its teachings. Malayalam catholic Bible reads, "If anyone should cause 'othappu' to those little ones, it would be better for that person to have a large milestone tied around his neck and be thrown into the sea" (Mark 42-3). In short, the idea of 'othappu' is an ideological tool employed by the church to prevent any attack on its system. So 'othappu' is a moral constraint and a mechanism of control.

It should be noted that 'othappu' is a double edged sword that can turn out to be both a mechanism of control and a tool of resistance or subversion, as in the case of Bhabha's mimicry. The act of 'othappu' has two important aspects. First of all, it involves the enactment of an action that the church forbids, and secondly it turns out to be an instigation or temptation for others to emulate that forbidden act thereby deviating from the teachings of the Church. If the enactment of a forbidden act needs to be a temptation for others to emulate it, it must be committed publicly. For example, 
prostitution, according to the teachings of the church, is a sin. However prostitution turns out to be an act of 'othappu', only when it is committed openly. The person who commits 'othappu' instigates a believer to subvert the authority of the church by doing an act that the church despises. In other words, it not only challenges the teaching of the church but also spurs others to do the same act. An action turns out to be 'othappu' only when it causes a believer to lose his belief in the teachings of the church.

In Othappu, Joseph employs the concept of 'othappu' as a tool of resistance to subvert the authority of the church over its laity to liberate them from the constraints that the church imposes upon them. Margalitha's decision to defrock herself is a resistance to the church's norm that a priest or nun is not supposed to renounce their vocation. Paul Zacharia notes that "We tend to view the person who renounces the chosen path of celibacy as tainted..." (250). By defrocking herself Margalitha not only subverts this common belief regarding holy vocation but also shows her fellow members that it is all a matter of choice, and they can also do the same thing, if they feel like. Her offering of holy sacrament is an open flouting of the custom that the nuns are not allowed to offer holy sacrament. According to the teachings of the church, sexuality and priesthood are mutually exclusive ideas. By developing a romantic relationship with Father Karikkan, Margalitha who is a nun openly defies this notion. Being a nun, Margalitha is a public figure in the church and she is supposed to be a role model for the believers. The believers, the church hopes, will learn from a priest or a nun as to how to live their life the right way. When a nun who is supposed to uphold the teachings of the church in public commits a prohibited act, it turns out to be a temptation for her followers to do the same act. By openly committing all the acts that the church sees as anathema, Margalitha causes 'othappu' not only to the common believers but to 
her fellow members of the church as well. Margalitha turns othappu into a powerful tool of subversion and resistance.

The same is the case with Brother Manikyan and Father Augustine who have severed their ties with the kind of Christianity that Catholic Church professes. Father Augustine subverts the accepted structure of celebrating the sacrament of Holy Mass. He does it publicly thereby showing that anybody has the authority to perform it in whatever ways one wants. In the eyes of the church it is an act of 'othappu', but it functions here as a way of resisting the authority of the church. In the eyes of the church, Brother Manikyan's attempt to set up a 'black seminary' where people, especially the lower casts, can search for God through nature is an act of 'othappu' because the ideas of Manikyan's black seminary is at logger heads with the teachings of the church. It causes others to lose their faith in the framework of the church. Rebecca is another character in the novel who employs 'othappu' as mechanism of resistance against the church. She publicly rebels against the conventional faith practices of the church by claiming that she has direct link with Christ and can heal people. She cures the sick and consoles hundreds of people who ignore the church and flock to her prayer sessions. Her parallel religious practices that draw people away from the teachings of the church are obviously an act of 'othappu'. But this 'othappu' is not a means of control rather it is an empowering position. In short, the entire novel functions as an 'othappu', an attempt to challenge the authoritarian teachings of the church.

But in the translation, Thampu does not see 'othappu' as a form of resistance. Although he agrees to the view that 'othappu' is a mechanism of control, he treats it as evocative of a strong desire for the forbidden and the dilemma resulting from it. Thampu notes 
"Not to conform is to cause 'othappu'. But to conform is to court unfulfillment. How can we sing the songs of our hearts without disturbing the stability of the status quo? It is this archetypal dilemma that Sarah Joseph encapsulates in the title 'othappu' (Thampu: xii).

Thampu says that the title The Scent of the Other Side is "imaginative and thematic" (Thampu: xii). According to him, the naming of the text as The Scent of the Other Side is the "result of engaging with the text as a whole from the perspective of a translator" (xii). The title The Scent of the Other Side expresses the idea of passion for the forbidden wishes. The Oxford Advanced Learners' Dictionary defines the term 'scent' as 'the pleasant smell that something has" (Wehmeier: 2005). Though the idea of what a pleasant smell is highly debatable, everybody will agree to the point that the pleasant smell is something that everyone loves to experience. Now let's see what the other part of the title - the other side-indicates. If we juxtapose the term 'the other side' against its binary opposite 'this side', we will see that the position of the 'other side' is always on the right side of the pair of binary opposites (this side/the other side). It is obvious that the usual practice is to valorise the left side of the binary pair over the right side. For example, hero/villain, right/wrong. The positioning of the 'other side' on the left implies its unacceptability in society. Hence the title The Scent of the Other Side means a tantalizing experience that is unacceptable. The title does not treat the term 'othappu' as a tool of resistance which Sarah Joseph does in the source text. So the change of the title from 'Othappu' to 'The Scent of the Other Side' marks a complete shift from the intention of the source text.

Another case of discontinuity in point is the translation of the term 'kavu' into 'woods' and 'forest'. For Hindus in Kerala, 
'Kavu' is an ecological haven where the serpents are worshipped. In the source text, Sarah Joseph employs the term 'kavu' to refer to the place where the Dalit Christian Brother Manikyan performs his Black Liturgy. The dalit Christians are the lower-caste Hindus who converted to Christianity to escape the oppressive caste system in Hinduism. Though they left their Hindu identity, the Dalit Christians could not wriggle out of the clutches of their identity as lower caste in Christianity either. Their identity as lower caste in Hinduism got carried over to Christianity thereby making them recipients of similar caste oppressions that they wanted to escape through conversion. Being a Dalit Christian, Brother Manikyan also faces similar oppressions. Although Brother Manikyan is an aspirant priest, he is not allowed to join seminary and to become a priest because of his dalit identity. Neither in Hinduism where he was born into, nor in Christianity where he converted to, Brother Manikyan is valued. By performing liturgy which is a Christian ritual in a place like ' $\mathrm{Kavu}$ ' which is sacred to Hinduism, Brother Manikyan portrays a hybridization of Hinduism and Christianity. This idea of hybridity is literally embedded in the expression 'liturgy in Kavu' (Kavile Kurbana). By performing a ritual which is a mixture of Christianity and Hinduism, Brother Manikyan, who is alienated from these institutionalized religions, is in fact creating a third space for himself.

According to Bhabha, hybridity is also a challenge to the notion of purity upheld by the dominant structures. The reason why Manikyan is not allowed to become a Christian priest is that he is a converted Christian. In other words, he is not a 'pure' Christian or a Christian by birth. By reserving the right to become a priest only to those who are Christians by birth and by not allowing laymen and nuns to perform liturgy, the Church subscribes to the notion of purity. The same is the case with Hinduism where the lower-castes 
are not allowed to be part of the mainstream Hindu society as well as the temples. In this scenario, hybridity becomes a means of resisting the idea of purity to uphold multiplicity and plural identities. Bhabha notes, "It[hybridity] displays the necessary deformation and displacement of all sites of discrimination and domination. It unsettles the mimetic or narcissistic demands of colonial power but reimplicates its identifications in strategies of subversion that turn the gaze of the discriminated back upon the eye of power (Bhabha: 159-160). Brother Manikyan who is alienated from both Hinduism and Christianity not only creates a third space for himself by mixing these two religious structures, but also subverts their notion of purity by contaminating them. Valson Thampu's translation of 'liturgy in Kavu' into 'liturgy in forest' takes away this concept of hybridity in religious practice and the resultant resistance to the claim of purity attributed to the institutionalized religions. According to Thampu's translation, Manikyan is only performing the Christian religious practice of liturgy in a 'forest'. The term forest fails to evoke the idea of subversive hybridity that the term 'kavu' can generate in conjunction with the word 'liturgy'. So the kind of cultural symbiosis inherent in the expression 'the liturgy in the kavu' is lost in translation.

Another discontinuity in point is the translator's expurgation of the character Yohannaan Kasseesa's take on Charismatic meetings. In the source text charismatic meetings are dubbed 'spiritual masturbation' (atmiya swayambhogam). But in the translation, Thampu readily translates the expression 'spiritual masturbation' into a euphemistic theological expression 'spiritual self-indulgence'. Quoting Yohannaan Kasseesa, Father Karikkan says, "The so called deadly diseases are all, in point of fact, mental. Also the Syrian Christian Bishop says that charismatic meetings are spiritual self-indulgence" (Thampu: 15). Charismatic meetings are 
the prayer meetings conducted by the church where the participants can supposedly feel the presence of the Holy Spirit and rejuvenate their faith. It is believed that the attendees often receive spiritual gifts from the Holy Spirit in the form of deliverance from their personal afflictions. The criticism that is often directed against the charismatic meeting is that the practitioners of charismatic meeting often focuses on the personal gains that people get through the holy spirit such as redemption from sickness, and lose the sight of its ultimate aim, that is the rejuvenation of spiritual life.

To reveal the damage that Thampu's translation inflicts on the text, we need to understand what spiritual self-indulgence is and why Thampu replaces the term spiritual-masturbation with 'spiritual self-indulgence'. According to Martin G Collins, "Self-indulgence is excessive satisfaction of our sensual appetites and desires for the specific purpose of pleasing the self" (Collins 14). Self-indulgences are of various sorts like the desire for sexual-gratification; the desire for wealth; the desire for one's own way. Even prayer can become self-indulgence if it is for the fulfilment of selfish motives. Christianity teaches that all our actions should be for the welfare and wellbeing of the society, as opposed to parochial personal interests. Charismatic meeting is called self-indulgence primarily because of its preoccupation with the gifts that Holy Spirit confers on the attendees. More than focusing on the good of the society, charismatic meetings often get reduced to the personal benefits of the participants. In Othappu, we can see believers flocking to charismatic meetings for the fulfilment of their personal needs. In Christian theology, masturbation is self-indulgence because it aims only at the pleasure of the self. Unlike the sexual-intercourse in marriage, masturbation does not involve the production of progeny which is a contribution to the society. Since masturbation is an activity oriented towards the pleasure of the self, Thampu supplants 
the word masturbation with the umbrella term 'self-indulgence' which covers all the activities for the pleasure of the self.

Even though the replacing of the term 'masturbation' with 'self-indulgence' does makes sense from a theological point of view, it is at logger heads with the ideology of Yohannaan Kasseesa who makes this comment. Kasseesa does not see the church as a divine mechanism. For him church is just an institution like any other institutions in the society like a bank, school or college, and Christ is only a leader, rather than a metaphysical agent who controls everything. Quoting Yohannaan Kasseesa, Father Daniel says "He held that church was only an institution" (Thampu 15). By employing the term masturbation, what Yohannaan Kasseesa means is that charismatic meetings do not involve the presence of God who is believed to magically offer the attendees deliverance during the charismatic meeting. To understand how the term spiritual masturbation conveys this idea, we need to look at the implication of the term 'masturbation'. Unlike sexual intercourse, masturbation is a way of deriving sexual gratification without the active assistance of an external agent. When he calls charismatic meetings 'spiritual masturbation', it is this idea of the absence of an external agency inherent in term masturbation that Kasseesa aims to invoke.

The major claim of the practitioners of charismatic meeting is that it involves the presence of the external agency God who bestows upon the attendees gifts in the form of deliverance from their afflictions. In the novel, Father Daniel, Rebecca and Doctor Chandy are the charismatic leaders who propagate this notion. Rebecca and Chandy claim that in their charismatic meetings, they have brought deliverance to the afflicted. Father Daniel, as staunch believer of charismatic meetings, flares up with Father Karikkan, when the latter says that ailments like mental disorders, cancer, and 
blindness cannot be healed through charismatic meetings. Through the term spiritual masturbation, Yohannaan Kasseesa covertly informs us that the so called spiritual activities which are supposedly characterized by the intervention of the metaphysical elements are actually devoid of the mediation of any divine force. The phrase spiritual self-indulgence can only denote that it is a spiritual activity that is oriented towards the pleasure of the individual self. The adjectival phrase 'spiritual masturbation' is consciously employed to sever the metaphysical intervention attributed to charismatic meeting.

The discontinuities that incur ideological problem in the translation cannot be limited to syntactical variations alone. It is very much present in the formalistic aspects of the translation as well. An important stylistic feature of the source text is its unnamed chapters. In translation, all these unnamed chapters are titled. Thampu says about his decision to name the chapters of the novel, "Her [editor Mini Krishnan's] suggestion that the chapters of this novel be given specific titles-as against their sequential numbering in the original - is a creative suggestion that has enhanced the flavour of the text" (xiv). The decision to title the chapters, I would say, is not a creative move at all. To use a Deleuzian phrase, an untitled text is nomadic in nature. Borrowing from the nomadic lifestyle, Deleuze uses the term nomadic to denote a free distribution, rather than the structured organization of elements. For nomads, every site they reach is only a temporary centre to be left behind. Just as there is no fixed station for a nomad who moves across the space in sharp contrast to the static boundaries of State, so also an unnamed text is open to umpteen numbers of interpretations. In an unnamed text, there is no authoritative force to define what the text is. By not naming the chapters, Sarah Joseph releases the text to its infinite possibilities of interpretation, and frees the text from the potential 
threat of ontological certitude. In translation, all these unnamed chapters in the source text are properly titled, thereby ascribing a particular essence to the discourse. By naming these chapters, Thampu defines what the text is all about, and arrests the nomadic movement of the unnamed chapters. To put it differently, naming is a process of privileging a particular reading and silencing the other potential meanings. A case in point is chapter two which is titled 'A Corpse in the Colony'. By naming the chapter 'A Corpse in the Colony', Valson Thampu declares that the focal point of this chapter would be the corpse found in the municipality colony. In this way, Thampu silences the possibility of dialogism in the text.

The naming arrests not only the movement of the text, but that of the reader also. The names ascribed to the text define what the text is and prevent the reader from having a creative space to 'experiment' with the text. Here the term experiment means the act of interpreting the text from different ideological standpoints. A nomadic text invites the reader to experiment with it. Since the chapters in the source text are not defined through any specific titles, the text is open for the reader to define them in whatever way s/he wants. In other words, as Deleuze puts it, the text was originally open for experimentation. To experiment is to try new actions, methods, techniques and combinations 'without aim or end' (Deleuze and Guttari: 373). Experimentation is an open -ended process that constantly probes into what is new and what is coming into being rather than being already experienced and known. When the author leaves the chapters unnamed, thereby not imposing any specific meaning to the text, Thampu, the translator, essentializes the chapters by titling them.

The source text is also noted for the incorporation of a whole lot of decontextualized Biblical passages. For example, in 
chapter twelve, Rebekka says about Margalitha, "The stone that the builders reject has to become the cornerstone" (Joseph: 124). This passage is taken from Isaiah 8:13-14 in the Bible. In the Bible, the stone that the builders have rejected refers to Jesus Christ. In the context of the Scripture, this passage means that even though Christ was crucified and rejected by the rulers of the period, later on he would become central to the church and humanity. Here Margalitha, who was denounced by the authorities of the church, stands for Jesus Christ, and Rebecca proclaims that she will soon become a support to humanity, as it happened in the case of messiah. In chapter twelve, to cite another example, father Karikkan asks, "Can an authority set the people free?" (156). This passage is taken from St. Luke 4:18 in the Bible. Karikkan employs these words from the Bible when he reads the appointment letter from the church that 'authorizes' him to 'administer' the people in the parish. Upon reading the letter, he thinks: "Can he who administers be a friend to offenders and sinners? The way of authority will be in perpetual conflict with the way of forgiveness" (156). Through the Biblical passage 'Can an administrator set the people' free, Karikkan is challenging the authoritarian disposition of the church.

While Joseph employs these Biblical passages without informing the readers that they are taken from the Scripture, Thampu cites the source of these passages through foot-notes. Before analysing what discontinuity is generated by these footnotes, it is necessary to think why Sarah Joseph does not cite these Biblical passages. The primary intention of Joseph is to liberate these passages from the authority of the church. Charles W Hedrick says, "To recognize a citation is to conceive of a piece of writing as a rewriting, or an inscription: the evocation of another pre-existing (even if unapparent) text. In a more general way, the citation also works to defer its authority for utterance elsewhere" (141). The 
transposition of a passage into a new context makes it undergo an incorporeal transformation in the sense that although the passage does not have any physical change, they undergo a transformation in terms of the message that they convey.

Joseph views that since the same passage can mean differently in different contexts, they are 'new articulations' in each new context. In short, the transposition of these passages into a new context makes them new and original thereby releasing these set of signifiers from the grip of an authority. This inter-textuality, Kristeva says, does not confer the title 'source' upon the text from where a passage is transposed. She considers the transposed text as a 'new articulation' because it conveys a new order of signification. Kristeva writes, "The term intertextuality denotes this transposition of one (or several) sign system (s) into another, but since the term has been understood in the banal sense of 'the study of sources', we prefer the term transposition because it... demands a new articulation of the thetic....' (Kristeva: 59-60).Joseph proves that nobody can claim to have authority over a text because as the text gets transposed to a new context the meaning also changes, thereby becoming a new articulation. It should be noted that Joseph's employment of these passages is in the line of liberation theology of which the elemental concern is to interpret the teachings of Jesus Christ for the redemption of the marginalized from the socio, political and economic injustice. Liberation theologians understand the bible against the backdrop of a specific agenda and questions the wisdom of enquiring the 'true', 'original' or 'definitive' meaning of the Bible, as opposed to the Church's claim that the truth concerning the scripture is monolithic in nature.

For the church, liberation theology which interprets the scripture against the backdrop of contemporary issues is a cultural 
challenge to the Biblical truth. They hold that the Bible can be interpreted only in the ways that the prophets who have written these passages have intended. This shows that the authority of these passages rests with these prophets. In his opening speech at the Puebla Conference, Pope John Paul II criticized the liberation theology saying that, "this conception of Christ, as a political figure, a revolutionary, as the subversive of Nazareth, does not tally with the Church's catechisms" (Pope John Paul II 46). Central to John Paul's response to liberation theology is his determination to reclaim for the traditional Church many of the words that liberationists have tried to redefine. By transposing the Biblical passages into a new context and creating a new order of signification for them, Sarah Joseph liberates the Biblical passages from the onus of monolithic meaning. This is the reason why she does not invoke the authority of these prophets through citation. By citing the names of the prophets who have uttered these passages in the Bible as the creators of these passages, Thampu reinstates the Biblical authority over these passages. When Sarah Joseph attempts to subvert the Biblical authority over these passages, Thampu hijacks that move by citing the names of the prophets as the authority of the passage.

A symptomatic reading always necessitates the importance of being faithful to the source text, and shows that the ideology of the text is as important as its semantic content. It places on the translator a heavy task of being truthful not only to the source text but also to the target reader because translator is the only agent of representing the source text for the readers in the target language. The symptomatic reading of The Scent of the Other Side shows that it is a rewriting of the source text which is a resistance to various kinds of authorities in the society. The ideological problems that have sneaked into the translation The Scent of the Other Side shows that the translator has ceased to establish what Spivak calls an 
'intimacy' with the source text. To quote Spivak, a translator must "surrender to the [source] text" (205). A translator can surrender to the source text only by paying equal attention to the logic and the rhetoric of the source text. Logic is that process of moving from one word to another by making connections. Rhetoric is that quality of the language to convey an ideology without stating it explicitly. A translator's engagement with the logic of translation should not be at the cost of the rhetoric of the source text. The symptomatic reading of The Scent of the Other Side very clearly shows that Thampu has failed to analyse the rhetoric of the source text thereby making translation a pale shadow of it.

\section{REFERENCES}

Antony, Shinie. 2010. "Morality among Mere Mortals". Indian Literature. 54 (2). PP.249-251.

Bhabha, Homi. 1995. Location of Culture. London: Routledge.

Buchanan, Ian. 2010. Oxford Dictionary of Critical Theory. UK: Oxford University Press

Collins, Martin.G. 2014 April 22. "Overcoming Self Indulgence". Retrieved from http://www.cgg.org.

Deleuze, Gilles and FelixGuattari. 1987. A Thousand Plateaus: Capitalism and Schizophrenia. Tr. By Brian Massumi, Minneapolis:University of Minnesota Press.. Print

Joseph, Sara.2005.Othappu. Thrissur: Current Books.

Joseph, Sara. 2009. Othappu: The Scent of the Other Side. Trans. Thampu, Valson. New Delhi: OUP.

Kristeva Julia. 1984. Revolution in Poetic Language. New York: Columbia University Press.

Visudha Bible. 1963. Bangalore: Bible Society of India \& Cylone.

Paul, D Babu. 2009, July 19. "Cross Examination". Indian Express. Retrieved from http://www.archive.indianexpress.com. 
Pope John Paul II. 1979, January 28. Address of His Holiness John Paul II. Lecture Presented at Puebla, Mexico.

Spivak, Gayatri Chakravorty. 1993. Outside the Teaching Machine. London: Routledge.

Thampu Valson. 2009. “Translator's Note.” Translator's Note. In The Scent of the Other Side (pp. xii-xiv). New Delhi: OUP.

Venuti, Lawrence. 1998. The Scandals of Translation: Towards an Ethics of Difference. New York: Routledge.

Wehmeir, Sally., ed.2005. "Scent." Def. 1. Oxford Advanced Learner's Dictionary of Current English.

Zacharia, Paul. 2009. "Many Meanings of 'Othappu'. In The Scent of the Other Side (249-254). 